\title{
Trestní evidence (na př́kladu písemností humpoleckého) politického úrradu první instance státní správy na počátku 20. století
}

Pavel Holub / holubpavel@centrum.cz

Katedra archivnictví a pomocných věd historických, Filozofická fakulta, Univerzita J. E. Purkyně $\checkmark$ Ústí nad Labem

\begin{abstract}
The administrative work of criminal proceedings is a rich source of information on the life of the population of a given region. Although many regulations were issued as early as the 1850s, they continued to be valid during the First Czechoslovak Republic. Changes in society and the increasing pace of life also forced an acceleration in criminal proceedings. In 1936, so-called block criminal proceedings were introduced by the government. During the Second World War, the form of accounting for criminal activity forced new regulations. An examination of documents of the former District Office of Humpolec revealed various types of documents that were typical for this kind of administrative work. Although the most frequently used term is criminal register, the meaning of it was not always clear.
\end{abstract}

\section{Keywords}

criminal administrative proceedings, criminal proceedings, fine, criminal records, first half of the 20th century 
Spisy týkající se vyšetřování překročení normy představují cenný zdroj informací o každodenním životě společnosti daného regionu a doby. ${ }^{1} \mathrm{~V}$ průběhu staletí se vyvíjelo nejen trestní řízení projednávané u soudů, ale i trestní řízení „přestupkové“. Z období 19. a 20. století bychom se s výsledky těchto řízení setkali u mnoha institucí. Svůj příspěvek jsem se ovšem rozhodl zasadit do období konce rakousko-uherské monarchie a do doby existence první republiky. Hlavním zdrojem informací se staly především písemnosti někdejších okresních hejtmanství (po roce 1918 okresních správ politických, od roku 1928 okresních úřadů) v Humpolci, Pelhřimově a Kamenici nad Lipou, jejichž fondy jsou uložené v Moravském zemském archivu v Brně-Státním okresním archivu Pelhřimov. V nich najdeme úřední knihy nesoucí název trestní rejstřík. Při hlubším prostudování předmětných knih často ovšem zjistíme, že pod týmž pojmem se skrývají dvě či tři rozdílné řady knih. Již v době jejich vzniku docházelo k jisté terminologické neustálenosti, která poté ovlivnila i podobu užitých názvů při archivním zpracování. Právě vzájemný vztah dvou shodně pojmenovaných, ale přitom obsahově rozdílných knih, vyvolává již první otázku po poměru mezi těmito svazky. Proč byly vůbec takové řady knih vedeny a jaké informace mohou současnému badateli poskytnout? V jakém kontextu trestního správního řízení se písemnosti proměňovaly? Zatímco pro středověké a raně novověké období se „popularitě“ z trestní agendy těší smolné knihy, ${ }^{2} \mathrm{z}$ období 20. století jsou využívány především trestní spisy vzniklé při velkých dějinných událostech. Naopak každodenní život a problémy „malého“ regionu často prosvítají ze spisů právě okresních úřadů, případně pozdějších okresních národních výborů. Po roce 1945 zde najdeme spisy vzniklé u trestních komisí, které reflektují kupříkladu řízení v rámci malého retribučního zákona ve druhé polovině 40. let 20. století nebo osudy venkovského obyvatelstva v období tzv. kolektivizace. ${ }^{3}$

1 O využití obdobných pramenů pro studium jednotlivých období viz výběrově: např. pro dobu raného novověku Malý, Karel: Trestni právo v Čechách v 15. -16. století. Praha 1989². Pro mladší období Dibelka, Jaroslav: K novým možnostem studia trestněprávni problematiky. Obranné strategie mužů a žen obviněných ze smilstva na třeboňském panství (1650-1750). Český časopis historický 106, 2008, č. 1, s. 19-53. Týž: Obranné strategie mužů a žen obviněných ze smilstva a cizoložství. Panství Třeboň na přelomu 17. a 18. století (= Monographia historica 12). České Budějovice 2012. V rámci disciplinace raněnovověkého městského obyvatelstva blíže např. Hrdlička, Josef: Víra a moc. Politika, komunikace a protireformace v předmoderním městě. Jindřichův Hradec 1590-1630 (= Monographia historica 14). České Budějovice 2013. Pro období baroka Čechura, Jaroslav: Sex v době temna. Sexuální život na českém jihu v prvním století Schwarzenberků (1660-1770). Praha 2015. Populárněji koncipovaný souhrnný přehled Francek, Jindřich: Zločin a trest $v$ českých dějinách. Nové vydání rozšířené o paměti prvního československého kata, Praha 2007. Kreuz, Petr: Proměny organizace trestniho soudnictvi v Čechách od tereziánských reforem do roku 1848. In: Zločin a trest v české kultuře 19. století. Sborník příspěvků z 30. ročníku sympozia k problematice 19. století. Plzeň 25.-27. února 2010. Ed. Petr Kreuz, Praha 2011, s. 19-28.

2 Francek, Jindřich - Šimek, Tomáš: Hrdelni soudnictvi českých zemí. Soupis pramenů a literatury. Praha Pardubice 1995.

3 Krčilová, Irena: Náprava křivd v padesátých letech 20. století způsobených nálezy národních výborů zemědělcům na Pelhřimovsku. In: Jaro ,68 a nástup normalizace. Československo v letech 1968-1971. Praha - České Budějovice 2017, s. 112-124. Kmoch, Pavel: Proviněni proti národni cti. „Malá retribuce“ v českých zemích a Trestní nalézací komise v Benešově u Prahy. Praha 2015. Kmoch, Pavel - Portmann, Kateřina: Pomsta, nebo spravedlnost? Trestní nalézací komise v českých zemích. Fontes Nissae. Prameny Nisy (regionální historický sborník) 12, 2011, s. 185-206. 


\section{Trestní ŕizení v kontextu norem}

Byl masopust roku 1928, když v malé obci, v Plačkově, tři kilometry východně od Humpolce „uspořádali truhlářský pomocnik Josef Kř̌žz z Plačkova čp. 39 a domkář Václav Jakoubek z Plačkova čp. 48 v osadě Plačkově maškarni prưvod, $k$ němuž žádného povoleni si nevyžádali. Josef Kř̌ž přistrojil [!] se za kněze pomoci bilé košile, zjednal školni děti... a hochy tyto přistrojil [!] pomocí záclon a čepic z papíru za ministranty. Za kněze přistrojeného Křriže a hochy ustrojené za ministranty vozil domkář Václav Jakoubek z Plačkova čp. 48 jedním koněm na bryčce v osadě Plačkově dům od domu. Jakoubek byl rovněž maskován jako koči s dlouhým knírem. Kř́ž tropil si při tom z církve řimskokatolické posměch, při vstupováni do domu pronášel slova: „Kyrie eleison, penize nejsou" a hleděl církevni obyčeje a zř́zeni zlehčiti. Ministranti vybírali přitom peněžité dary a prưvod bral se osadou až na dvi̛r obydli starosty Jakoubka. U starosty Jakoubka dlel právě na obchưzce vrchni strážmistr František Dostálek a při spatřeni četnika chlapci za ministranty ustrojeni utekli a Kř́žovi a Jakoubkovi pokračováni v nedovoleném prưvodu bylo zakázáno a masky museli odložiti...

Starosta obce Josef Jakoubek $k$ pořádáni průvodu též povoleni neudèlil a Kř́žz s Jakoubkem o povoleni u něho nežádali. Josef Kř́ž doznal vrchnímu strážmistru Františku Dostálkovi v př́tomnosti mistniho starosty osady Plačkova Bohumila Prokopa, že průvod bez povoleni s Jakoubkem pořádal, ústroj jeho měl znázorňovati katolického kněze a omlouval se opilostí. Vybiráni peněžitých darů a pronášeni posměšných slov popiral. Václav Jakoubek udal, že byl k činu sveden Kř́žem a vymlouval se též opilostí. O Kř́žovi i Jakoubkovi je známo, že rádi piji, ale v době pořádáni maškary nebyli tak opili, aby nevěděli, co čini a nebyli si vědomi pácháni jejich protizákonných činư. "4

Hlášení dokumentuje jednu z událostí, která rozjitřila jinak snad až příliš stereotypní život venkovské společnosti na Humpolecku v době počínající hospodářské krize. Spis ovšem představuje cenné svědectví o průběhu samotného úředního řízení a dovoluje diplomatikům 21. století nahlédnout na širší souvislosti celého úředního postupu a poodhalit tak vztahy mezi písemnostmi.

Z herálecké četnické stanice vrchní strážmistr František Dostálek zaslal své hlášení do Humpolce jak okresnímu soudu, tak i okresní správě politické. Ponechal institucím prostor k příslušné klasifikaci, zda bude případ projednán podle přestupkového řízení nebo naplní kritéria trestného činu. ${ }^{5}$ Přestože se událost stala 22. února, herálecký strážmistr vypracoval hlášení o měsíc později (29. března) a dokument byl na okresní politickou správu doručen až za další týden (presentován 3. dubna). Ve srovnání s tímto poněkud liknavějším postupem, samotný průběh projednání u úřadu byl „svěži“. Úřad vydal trestní nález již za tři týdny. Celá kauza byla vedena v rámci trestního řízení.

4 Moravský zemský archiv v Brně - Státní okresní archiv Pelhřimov (dále MZA Brno-SOkA Pelhřimov), Okresní úřad (dále OÚ) Humpolec, inv. č. 810, kart. 242 - maškarní průvod v Plačkově.

5 U mnohých spisů lze vidět toto přehodnocení i dnes. Spisy obsahují často obal, v němž jej okresní soud postoupil i se svou spisovou značkou a dalšími údaji okresnímu úřadu (např. u nepovoleného styku se zajatci za první světové války - MZA Brno-SOkA Pelhřimov, OÚ Humpolec, inv. č. 817, kart. 243 - vyšetřování nedovolených styků se zajatci). 
U úřadu užívajícího zásady oberhollabrunnského systému (s humpoleckými úpravami) ${ }^{6}$ byly spisy již při podání odděleny od ostatní agendy a zapisovány do řady podacích protokolů označených písmenem „, $R^{\prime \prime}$ - trestní agenda. Spis navádí k položení si zásadní otázky, na níž neměl jasnou odpověd’ ani herálecký strážmistr František Dostálek. Měl ř́zení s plačkovskými výtržníky provést politický (správní) úřad nebo soud? Pro hledání odpovědi je třeba si představit vývoj a stav trestního řízení v průběhu 19. a 20. století.

V období první republiky byl převzat systém členící překročení normy do tří skupin, totiž na: a) zločiny, b) přečiny, c) přestupky. Toto rozdělení bylo v rakousko-uherské monarchii zavedeno v polovině 19. století, přičemž navazovalo na zákon z roku 1803, jenž rozlišoval pouze zločiny a těžké policejní přestupky. Těžký policejní přestupek v této době nesměl splňovat některý z charakteristických znaků zločinu, a to „bud’ úmysl zlého, bud' bezprostředního porušeni práva neb konečně jisté značnosti zpuisobené škody “8 Skupina těžkých policejních přestupků se následně roku 1852 rozdělila na přečiny a přestupky. Rozdíl mezi nimi spočíval především v institucích kompetentních $\mathrm{k}$ jejich řešení. $\mathrm{Z}$ hlediska přesné definice pojmů v legislativě neexistovalo vymezení, ale dovozovalo se, že za přestupky a přečiny se označovaly ty delikty, při kterých nebylo prokázáno vůbec nebo jen z části zlého úmyslu, případně došlo k porušení obecného právního řádu, nebo práv jednotlivců $\mathrm{s}$ menším rozsahem. Trestní zákon posléze přesně vymezil soudům, které přestupky budou jimi řešeny. ${ }^{9}$ Navíc nově vydávané zákony v části věnované sankcím určovaly instituce, které byly oprávněné v dané záležitosti provádět trestní řízení. Přestupky tak směly projednávat především okresní soudy nebo policejní (správní) úřady.

$\mathrm{V}$ době rakousko-uherské monarchie docházelo $\mathrm{k}$ upřesnění některých institutů přestupkového řízení rovněž ministerskými nařízeními. Přestupky, o kterých rozhodovaly soudy, byly přestupky soudními, ty, o nichž rozhodoval správní úrad, byly přestupky policejními, pokud je projednával finanční úřad, jednalo se o přestupky důchodkové. $\mathrm{O}$ přestupcích rozhodovaly rovněž obce a to tehdy, pokud věc náležela do oboru místní policie. $^{10}$

Proměna společnosti se logicky promítala i do obsahu této agendy a následně i do písemné produkce konkrétních úřadů. Pokud nedošlo k vyskartování celé trestní agendy

6 Blíže k jeho reflexi Holub, Pavel: Oberhollabrunnský systém spisové služby a okresni úrad v Humpolci v polovině 20. století. Archivní časopis 61, 2011, č. 1, s. 5-78; v prostředí samosprávy v českém prostředí Tomas, Jindřich: Oberhollabrunnský systém spisové manipulace u městského úřadu v Žatci. Archivní časopis 7, 1957, č. 2, s. 76-83. V rakouském prostředí Hochedlinger, Michael: Aktenkunde. Urkunden- und Aktenlehre der Neuzeit, Wien - München, 2009. s. 111-114.

7 Komplexní přehled vývoje přestupkového řízení od 18. do 20. století nastiňuje Vetešník, Pavel: Řizeni prestupkové. In: Encyklopedie českých právních dějin (XI. svazek, Řizení). Ed. Karel Schelle - Jaromír Tauchen. Plzeň - Ostrava 2018, s. 578-584. Rovněž i Hlavačka, Milan: České země v 19. století. Proměny společnosti v moderní době II. Praha 2014, s. 167-186.

8 Rieger, František Ladislav: Slovnik naučný (díl šestý, P-Quo). Praha 1867, s. 901.

9 Veselý, František Xaver: Všeobecný slownik právni. Příruční sborník práva soukromého i veřejného zemí na radě ř́̌šské zastoupených se zvláštním zřetelem na nejnovější zákonodárství a poměry právní zemí koruny české (díl třetí, Padělání peněz-Pych vodní). Praha 1898, s. 874.

10 Vetešník, P.: Řizení přestupkové, s. 578-579. Martínek, Zdeněk - Pokorný, Radek - Šulc, Ivo: Metodika $k$ archivnimu zpracováni fondi̊ typu „Archiv obce“. Sborník archivních prací 68, 2018, Supplementum 1/2018, s. 28,33 . 
z registratury daného úřadu, můžeme se setkat (případně alespoň ve vzorcích) s velmi širokou „paletou“ přestupků. Z nejčastěji porušovaných předpisů jmenujme alespoň výběrově: živnostenský řád (neoprávněné provozování živností), branný zákon, zákon o osmihodinové pracovní době, epidemický, úrazový zákon, či zákon na ochranu domácího trhu a řadu dalších.

Obecné principy přestupkového řízení vymezily právní předpisy, jakým byl řŕšský zákon č. 117/1852 ř. z. o zločinech, přečinech a přestupcích. Ten byl prováděn trestním řádem z roku 1850 (č. 25/1850 ř. z.), resp. řádem z roku 1853 (č. 119/1853 ř. z.) a naposledy novelizovaným řádem z roku 1873 (č. 119/1873 ř. z.). Mezi předpisy obsahující přestupkové řízení patřilo i císařské nařízení z roku 1854 (č. 96/1854 ř. z. ${ }^{11}$ ), jímž se vydávala norma určující politickým a policejním úřadům, jak vykonávat nařízení a nálezy jimi vydané. Rovněž sem náleží nařízení č. $61 / 1855$ ř. z. ${ }^{12}$, č. $34 / 1858$ ř. z. ${ }^{13}$ a č. 129/1858 ř. z. ${ }^{14}$

U přestupků v zásadě platilo, že každý skutek měl být co možná nejjednodušším způsobem vyhledán. V př́ípadě některých správních deliktů (uvedených v § 12) postačovalo prohlášení úředníka, případně starosty obce, že se skutek stal, jak uvedl, a nebylo třeba dalších důkazů. Císařské nařízení rovněž stanovilo, kdo a za jakých podmínek mohl vykonávat trestněprávní pravomoc, stejně jako podmínky podávání stížností nebo odvolání. Trest za spáchaný přestupek a přečin mohl mít různou podobu: peněžní pokuta, propadení věci, ztráta práv aj. ${ }^{15}$ Ve spisech se objevuje možnost výběru formy trestu, a to bud' $\mathrm{z}$ peněžité pokuty, nebo z uvěznění ve věznici okresního soudu.

\section{Dokument - Trestní rejstř́k}

Z naplňování výše zmíněných norem vznikalo několik skupin písemností. Přirozeně jako u každého úřadu z období novověku se to i v trestně správní agendě přímo „hemži“ spisy. Ty jsou tvořeny jednotlivými dokumenty. Velmi často se iniciačním dokumentem stávala zpráva četnické stanice, udání sousedů, obchodní a živnostenské komory, konkurence či místní školní rady. Pokud byla ve škole zjištěna zanedbaná školní docházka žáka, prošetření a potrestání spadalo rovněž do režimu trestního správního řízení. Z právního pohledu ovšem takové řízení nezačínalo oznámením místní školní rady na hejtmanství (okresní školní radu), ale až předvoláním dané osoby na okresní hejtmanství samotným

11 Nařízení, jímž se vydává předpis, jak mají politické a policejní úřady vykonávat nařízení a nálezy jimi vydané.

12 Nařízení, jímž se podle nejvyššího rozhodnutí ze dne 14. září 1852, 10. ledna a 29. července 1853 a 4. února 1855 ustanovují úřady, kterým ode dne účinnosti trestního soudního řádu ze dne 29. července 1853 přísluší vyšetřovat a trestat přestupky, jež nejsou v trestním zákoně ze dne 27 . května 1852 prohlášeny za trestné činy, a kterým se zároveň stanoví rízení, jehož jest př̀i tom nutno dbát.

13 Vetešník, P.: Řizeni prestupkové, s. 578-579.

14 Nařízení, jímž se podle nejvyššího rozhodnutí ze dne 19. srpna 1858 vydávají ustanovení o způsobilosti k výkonu soudcovského úřadu ve věcech vyšetřování a trestání přestupků přikázaných politickým a policejním úřadům a jímž se zrušuje nařízení č. 321/1854 ř. z. 
úřadem. ${ }^{16}$ Aby byla záležitost vyřízena rychleji, mělo mít trestní správní řízení od poloviny 19. století charakter ústního jednání. Proto již v nařízení ministerstva vnitra z 5. března 1858 (č. 34/1858 ř. z. $)^{17}$ bylo nařízeno, že se k záznamu o jednání má využívat formulář trestního rejstříku (Strafregister), který byl obsažen v příloze zmíněné normy. Trestní rejstř́ik měl být složen z jednotlivých listů, které se na konci daného roku svázaly do fasciklu, k němuž měl být rovněž veden abecední index odkazující na čísla jednotlivých listů. Jeden list byl určen pro jeden projednávaný případ. Z celého ústního výroku měla být zaznamenána pouze obsahově nejpodstatnější část. Formulář obsahuje dvanáct položek: I. Číslo běžné / II. Jméno a příjmení, stáří, stav, živnost neb zaměstnání obviněného, a místo, kde se zdržuje / III. Jméno a příjmení, stáří, stav, živnost neb zaměstnání žalobníků, poškozených neb udavačủ a místo, kde se zdržují / IV. Vyznačení přestupku, z něhož jest obviněný nařknut / V. Jak se obviněný vyznal neb ospravedlnil / VI. Výpovědě svědků a znalců pro obviněného anebo proti němu / VII. Vyznačení toho, co a čím to samé se za prokázané má / VIII. Obsah a datum nálezu s vyznačením předpisu přestoupeného a potvrzení úřední / IX. Náhrada, jakáž se nálezem přisuzuje / X. Nález byl vyhlášen dne / XI. Nález byl vykonán dne / XII. Poznamenání. ${ }^{18}$

O vazbě mezi jednotlivými rubrikami a výslednou písemností, tedy trestním nálezem, svědčí výnos ministerstva vnitra z roku 1927. Ministerstvo apelovalo, aby úředníci důsledně vyplňovali příslušné rubriky, nebot’ obsah šesté rubriky měl být využit k formulaci „na základě jakého skutkového zjištěni úrad nález vynesl“ a rubrika sedmá měla sloužit „jako podklad k tvrzeni, na základě kterých pri̛vodnich prostředků dospěl ke skutkovému zjištěni. "19

V případě nutnosti, resp. obzvláštních okolností bylo možné přistoupit k protokolárnímu zápisu podle běžného způsobu. V takovém případě se mělo navíc upravit vyplnění konkrétních polí trestního rejstříku a do dvanáctého pole se měl zmínit odkaz na protokolární řízení. Ve spisech Okresního úřadu Humpolec se ovšem formulář trestního rejstříku vyskytuje velmi sporadicky. Mezi dochované patří právě ten, jenž zachycuje případ plačkovských výtržníků Josefa Kř́iže a Václava Jakoubka. Na závěr upozorněme, že podle normy z roku 1858 měl být vyplněný list Josefa Kříže a Václava Jakoubka vložen do fasciklu k ostatním a na konci roku spojen. V př́ípadě Humpolce byl ovšem připojen k dalším písemnostem týkajících se plačkovského případu (hlášení četnické stanice, aj.) a s nimi uložen do registratury jako součást spisu.

16 MZA Brno-SOkA Pelhřimov, OÚ Kamenice nad Lipou, inv. č. 1034, kart. 511 - oběžník Zemského úřadu v Praze čj. 13562 ai 1932. 12a-81/1932 z 18. ř́jna 1932.

17 Nařízení, jímž se vydávají předpisy o řízení ve věcech přestupků náležejících do působnosti politických úřadů.

18 Formulář popsán dle dokumentu MZA Brno-SOkA Pelhřimov, OÚ Humpolec, inv. č. 810, kart. 242 (maškarní průvod v Plačkově) užívaný ve 20. letech 20. století. V německé verzi připojen k ministerskému nařízení.

19 MZA Brno-SOkA Pelhřimov, OÚ Kamenice nad Lipou, inv. č. 1034, kart. 511 - oběžník Zemské správy politické v Praze čj. 353675 ai 1927. 14/A 3231 ze 17. záŕí 1927. 


\section{Dokument „Actum...”}

Z hlediska písemností vzniklých z trestního správního řízení je nejčastěji zastoupena varianta, kterou lze popsat na případu mlynáře Josefa Kletečky ze Starých Hutí u Kalište. ${ }^{20}$ Ten napsal 25. dubna 1915 dopis svému synovi Františkovi do Ameriky, v němž vylíčil stav probíhající války a postoje venkova k monarchii. Dopis svému adresátu nikdy doručen nebyl. Byl totiž zadržen, zaslán na humpolecké hejtmanství a tam prošetřován pro přestupek $§ 11$ císařského nařízení č. 96/1854 ř. z. z 20. dubna 1854. Skutková podstata jeho jednání byla popsána následovně: „v dopisu dne 25. dubna 1915 Vašemu synovi do Ameriky zaslaném nechut' proti vládě a podceňováni stávajicich poměrů v řiši rakousko-uherské [jste] projevoval“. JUDr. Josef Drábek 27. května obeslal dotčeného mlynáře, aby se dostavil k projednání na úřad v sobotu 5. června v 9 hodin ráno. Na co se konkrétně úředník ptal a co mu naopak mlynář odpovídal, to se dnes již nikdo ze spisu nedozví. Jisté je, že z celého jednání byl vyhotoven pouze záznam o jednání, jenž je (jako i v jiných případech projednávaných v rámci trestního správního řízení) uvozen formulí „Actum u c. k. okresniho hejtmanstvi v Humpolci dne... Dostavil se ... a udává..." Dokument je posléze ukončen zkratkou c. m., případně rozepsanou slovy coram me, znamenající přede mnou. Vždy je podepsán jak úředník, tak i vyslýchaná osoba. Dokument byl v době první světové války a i později vyhotoven rukou úředníka, který celé řízení vedl. Právě v době války bychom ve spisech hejtmanství našli velké množství takto projednaných záležitostí spjatých především s otázkami zásobování, zatajování zásob či „ketasením”.

Jako nepopiratelný důkaz o vině Kletečky svědčil jeho dopis. Projednání provinění bylo rychlé. Ještě téhož dne byl v kanceláři dr. Drábka vyhotoven koncept trestního nálezu. Protože množství projednávaných případů v trestním správním řízení bylo velké, měli na hejtmanství již připraven cyklostylový formulář, do kterého konceptní úředník vyplnil pouze konkrétní údaje a takto připravenou písemnost postoupil písárně k vyhotovení čistopisu. Posléze měla kancelář zanést záznam do trestního rejstříku (zde chápejme do knihy evidence pokut). Jak je ze zpátečního recepisu (dnešními slovy dodejky) patrné, mlynář trestní nález převzal 15. června 1915. Jeho druhopis zaslalo hejtmanství také humpoleckému soudu. Ten měl na písemnost zaznamenat, kdy mlynář vykonal trest vězení v délce 7 dnů, jenž mu byl vyměřen. Mlynář Kletečka trest vězení vykonal mezi 1. a 8. červencem roku 1915. I tuto informaci měl obsahovat trestní rejstř́ik (kniha evidence pokut) vedený u hejtmanství. Proto byla doba vězení na druhopise trestního nálezu poznamenána přesně (na hodinu). Druhopis s přípisem byl ještě 8 . července zaslán zpět na hejtmanství a informace poznamenána do rejstříku. ${ }^{21}$

20 MZA Brno-SOkA Pelhřimov, OÚ Humpolec, inv. č. 817, kart. 243 - zadržení dopisu do Ameriky.

21 MZA Brno-SOkA Pelhřimov, OÚ Humpolec, inv. č. 817, karton č. 243 - zadržení dopisu do Ameriky. 


\section{Cyklostylové formuláře}

Protože se v trestně správní agendě vyskytovaly obdobné typy písemností, bylo vhodné konceptní činnost nahradit formuláři. Lze tak rozeznat několik různých řad předtištěných formulářů, jejichž obsah byl posléze převeden v písárně do čistopisu, který se zaslal obžalované straně. Ve spisech humpoleckého úřadu z let 1910-1938 jsou zřejmé následující formuláře:

Výzva starosty k provedení výslechu a vypracování protokolu. Typickým znakem je uvození formulí „Zdejšímu úřadu bylo oznámeno...”. ${ }^{22}$

Výzva četnické stanici ke spolupráci při zjištění bližších informací. Signifikantním je odsazení jednotlivých požadavků na nové řádky začínající slovem „k vyšetřeni”. ${ }^{23}$ Tento formulář byl také užíván pro zjištování bližších informací při vydání živnostenského listu, přičemž pro trestní řízení byl adekvátní především pátý bod.

Trestní nález vždy začínal formulí „Vaším doznáním a provedeným vyšetřováním “.24 Ta byla od roku 1922 na základě výnosu zemské správy politické25 nahrazena „Pro přestupek...."26

22 „Panu starostovi města / obce v _.. Zdejšímu úřadu bylo oznámeno, že __ bydlící ve Vaši obci __. Pane starosto, vyslechněte obviněného /nou/ o udaném přstupku. O výsledku sepište protokol. Vyslýchaný jej musí podepsati. Tento protokol předložte zdejšimu úřadu do 14 dnů. Současně oznamte sem rodinné, majetkové a výdělkové poměry obvinèného. Okresni hejtman, rada politické správy:

Jednáno u obecního úř́adu v __ dne __vypovídá: __. Podpis náměstka, starosty obce:_. Podpis vyslýchané osoby: Číslo:__. Okresnímu úřadu v Humpolci po výkonu. Dodává se, že vyslýchaný /á jest ženat - vdaná - svobod__. Popis výdělkových pomeri̊_..

Datum: __ Podpis náměstka, starosty obce: __ “

(Např. MZA Brno-SOkA Pelhřimov, OÚ Humpolec, inv. č. 809, kart. 242 - stávka dělníků na stavbě silnice Senožaty - Syrov).

23 „Velitelstuí četnické stanice v

$K$ vyšetřeni rodinných, majetkových a výdělkových poměru jmenované(ho) žadatele (ky) a $k$ podáni zprávy, je-li ohledu hoden (na)

$K$ vyšetřeni a podáni zprávy, neni-li proti jmenovanému žadateli námitek ve smyslu $\$ 2,5,6$ a 18 živnostenského řádu a je-li týž - i členové jeho rodiny - zachovalý a spolehlivý, p. v. s.

$K$ vyšetřeni a podáni zprávy ve smyslu uvnitř uvedeného dožádání

$K$ vyšetřeni a podáni zprávy, zda uvnitř uvedené oznámeni jest pravdivé; p.v.s.

K vypátráni nynějšího pobytu jmenované (ho) __ (posledně v __ bydlicího a $k$ podání zprávy).

Spis vratte."

(Např. MZA Brno-SOkA Pelhřimov, OÚ Humpolec, inv. č. 809, kart. 242 - stávka dělníků na stavbě silnice Senožaty - Syrov).

24 „Panu _- ${ }_{\text {P_- }}$.

Vašim doznáním a provedeným vyšetřováním zjištěno, že dospustil (a) jste se přestupku __ tím, že ___. Pro tento přstupek odsuzuji Vás na základě ___ ku pokutě __ K, t.j. __ korun ve prospěch ústavu chudých obce __. V př́padě nedobytnosti do vězeni na _.. Z tohoto nálezu lze do __ dnů-počinaje dnem jeho doručeni - podati odvoláni $k$ c.k. mistodržitelstui v Praze u c.k. okresniho hejtmanstvi v

C.k. mistodržitelský rada, okresni hejtman, správce úřadu“

(Např. MZA Brno-SOkA Pelhřimov, OÚ Humpolec, inv. č. 817, kart. 243 - vyšetřování nepovoleného styku obyvatelstva se zajatci).

25 Výnos Zemské správy politické v Praze č. 4324 ai 1921 ze 4. 1. 1922 (normálka č. 208/1922).

26 „Pan _- $v_{-}$.

Pro přstupek __ ze dne __č́slo_, kterého jste se dopustil tím, že jste dle seznáni stráže, dle výpovědi svědku a dle svého částečného doznání Odsuzujete se podle __ $k$ peněžité pokutě __ Kč ve prospěch státní pokladny, v prípadě 


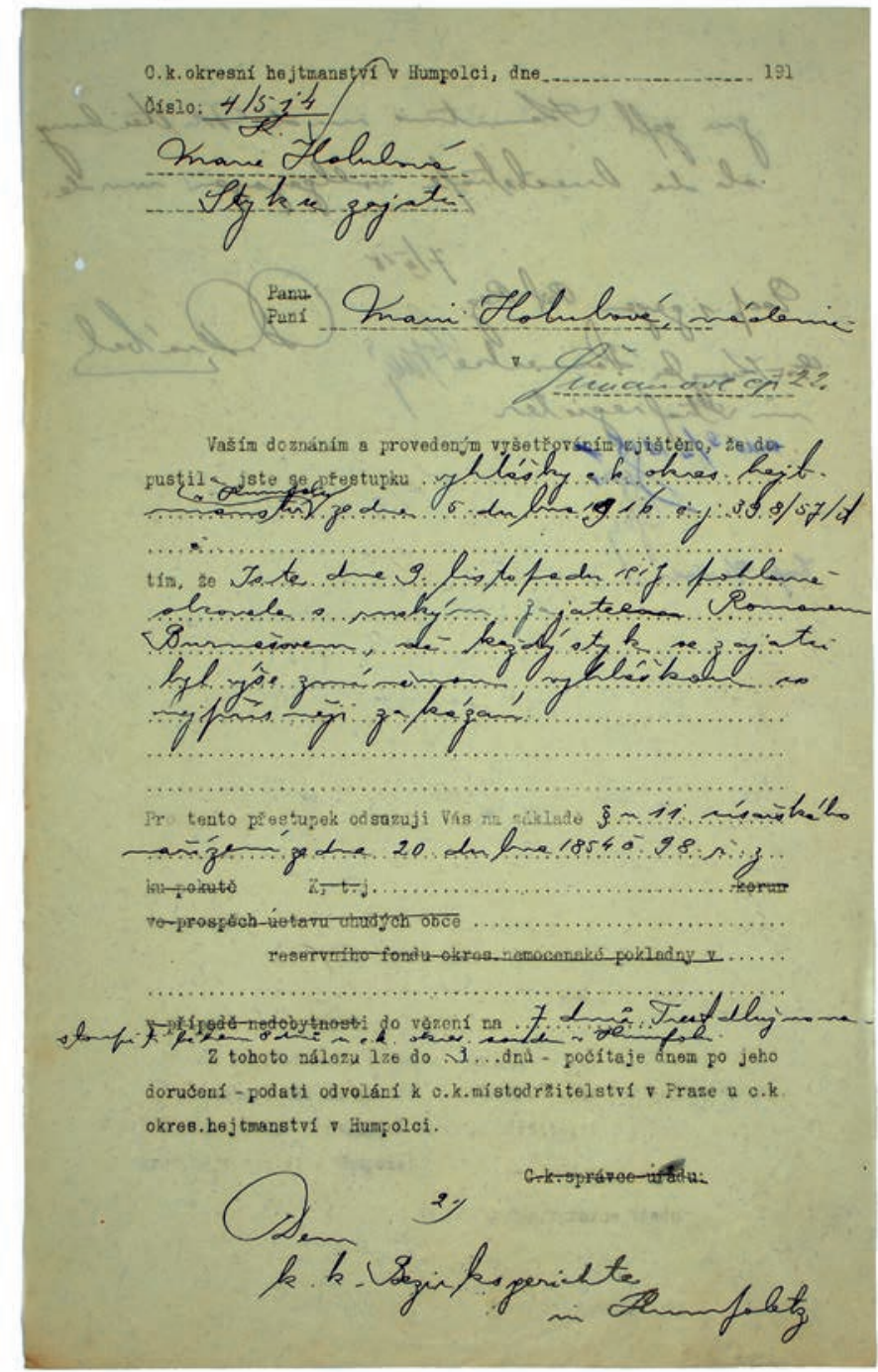

Obr. 1: Formulář trestního nálezu o přestupku (zákazu styku se zajatci za první světové války) spáchaného Marií Holubovou ze Šimanova čp. 22 (MZA Brno-SOkA Pelhřimov, Oú Humpolec, inv. č. 817, kart. 243 - vyšetřování nedovolených stykư se zajatci)

nedobytnosti $k$ vězení na dobu __ dnů - hodin. Pokutu zaplatiti jest přiloženou složenkou. Proti tomuto nálezu možno se odvolati do __ dnů počínaje ode dne následujicího po dni doručení u Okresního úřadu v Humpolci $k$ zemskému úřadu v Praze.

Exp. Duručte na potvrzeni a připojte složenku.

Viz kancelár za účelem záznamu v trestním rejstřiku a $k$ evidenci.

V trestnim rejstřiku pod $\check{c}$.__ poznamenal. “

(Např. MZA Brno-SOkA Pelhřimov, OÚ Humpolec, inv. č. 809, kart. 242 - stávka dělníků na stavbě silnice Senožaty - Syrov). 


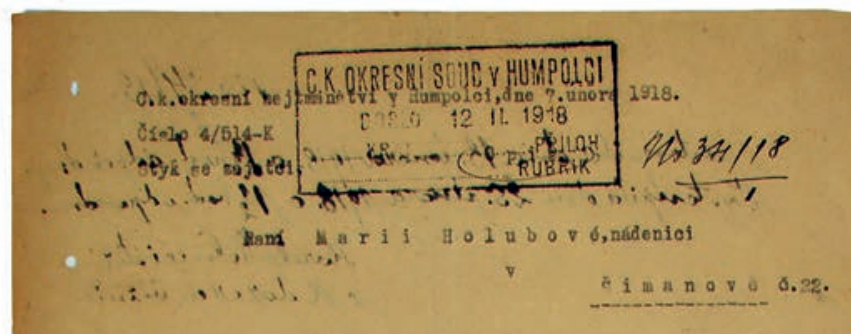

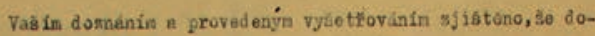
puatiladate se pleatupku-vyhiatzy o.k.okrempho he jtiranstvi $v$

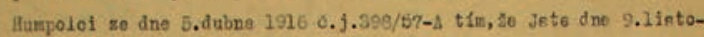
padu 1917 pohlavaé obcovala e rurikju zajatoes Romanes Rurnatovom

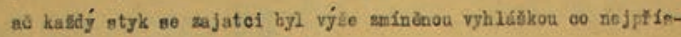
nưji zokásán.

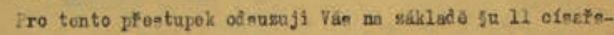

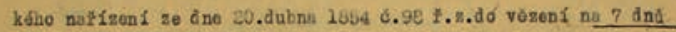

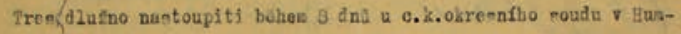
poici.

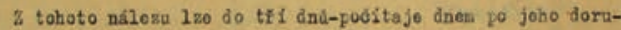

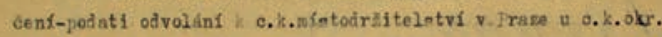
hejtranetvi $v$ Hurpoioi.

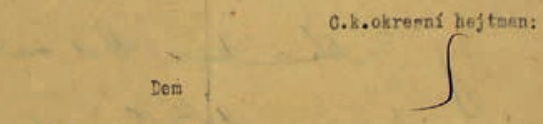

k.k. Bezirkegerichte

in

II $u=p 010 \mathrm{tz}$

zur gefl. Zemntrie und Witteilung ob die arreotetrafe rołlgesbgen murdo.

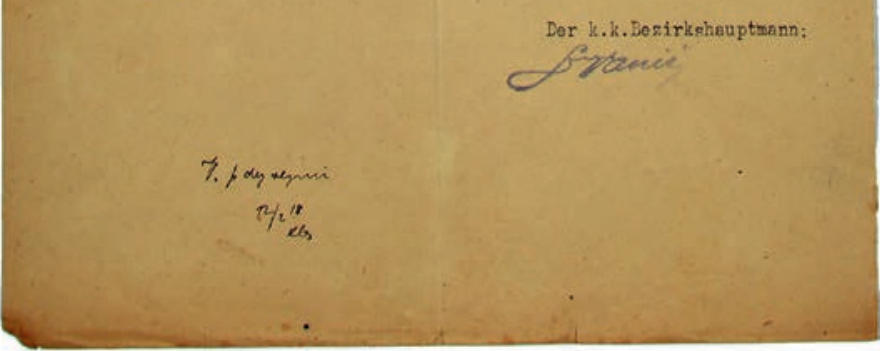

Obr. 2: Trestní nález vydaný pro Marii Holubovou ze Šimanova roku 1918 (MZA Brno-SOkA Pelhřimov, OÚ Humpolec, inv. č. 817, kart. 243 - vyšetřování nedovolených styků se zajatci)

Urgence k zaplacení pokuty či k výkonu trestu byla vždy uvozena formulí „Trestním nálezem...". ${ }^{27} \mathrm{~V}$ tomto případě se lze rovněž, ovšem velmi vyjímečně, setkat s předtištěným

27 „Panu _. $v$

Trestnim nálezem c. k. okresniho hejtmanstvi v Humpolci ze dne __ 191_číslo__ byl jste pro ___ odsouzen $k$ pokutě __ K ve prospěch __, v př́padě nedobytnosti k trestu vězenív trváni __ hodin. Protože jste tuto pokutu dosud neza- 
formulářem, který byl v Čechách zaveden v rámci užívání oberhollabrunnského systému. V Humpolci je ovšem doložen jen velmi sporadicky.

I u formulářů ve 20. století můžeme mluvit o určité filiaci jejich stylu. Formulář vycházel z obecné struktury písemnosti, pro niž sloužil jako koncept a která byla dána předpisem. Proto jejich proměny byly obecně dány normami, jak je zřejmé z formulace Trestního nálezu. Ovšem formuláře jako takové si úřady v jisté míře upravily a následně je v takovéto podobě mohly přejímat i další instituce. Je to patrné u spisu Františka Procházky z roku 1910. Zde úředník nově ustanoveného humpoleckého úřadu užil cyklostylový formulář havlíčkobrodského hejtmanství, jenž měl zřejmě ještě z prostředků, které si představitel úřadu Vojtěch Vaniš přivezl z Havlíčkova Brodu. Sám byl na ně jistě zvyklý, nebot' v Havlíčkově Brodě působil několik předchozích let.

\section{Kniha uložených pokut}

Jak bylo uvedeno, pojem trestní rejstřík označoval dokument pro záznam o řízení mající podobu volného listu, ale také pod tímto pojmem úředníci chápali knihu. I pro tento typ písemnosti - knihu byl užíván německý ekvivalent Strafregister. U jednotlivých úřadů se můžeme také setkat s jejím dalším označením jako Rejstřík pokut, ${ }^{28}$ ale častější je Trestní rejstřík. ${ }^{29}$ Jednalo se přitom o stále stejnou knihu, jejímž účelem bylo evidovat projednané trestně správní řízení a pokuty za ně určené. Právě fakt, že v nich byly evidovány pokuty, přiměl humpolecké úředníky k užívání termínu: Kniha uložených pokut. ${ }^{30}$ Zápis do knihy byl proveden po vydání trestního nálezu. Poté, kdy z okresního soudu byla doručena zpráva o výkonu vězení či od správce finančního fondu ${ }^{31}$ o zaplacení pokuty (před rokem 1928), byla zaznamenána i tato událost. Z rozboru formuláře je zřejmé, že knihy obsahovaly některé rubriky z formuláře trestního nálezu, ale její zápisy neměly právní vliv na podstatu věci (na jejím základě nebyly vyhotoveny trestní nálezy).

Do 20. let 20. století byly vybrané pokuty účtovány ve prospěch různých fondů. Aby se zjednodušil celý proces, přistoupila zemská správa politická k šetření o pokutách. K získání informací měly být využity právě trestní rejstříky, které měli úředníci vyexcerpovat.

platil, vybizim Vás, abyste řečený obnos sem bez srážky porta do __ zaslal, jinak na Vás pokuta politickou exekucí vymáhána bude.

C.k. správce úr̆adu: “

(Např. MZA Brno-SOkA Pelhřimov, OÚ Humpolec, inv. č. 826, kart. 245).

28 MZA Brno-SOkA Pelhřimov, OÚ Kamenice nad Lipou, kniha č. 216, 217; tamtéž, OÚ Pelhřimov, kniha č. 105 .

29 Tamtéž, OÚ Humpolec, kniha č. 157-161, ale i OÚ Kamenice nad Lipou, kniha č. 218, 220.

30 MZA Brno-SOkA Pelhřimov, OÚ Humpolec, inv. č. 822, kart. 244 - revize mlýnů.

31 V jejich prospěch byly skládány pokuty. Např. obecní chudinský fond, okresní nemocenská pojištovna, zemědělská nemocenská pojištovna, úrazová dělnická pojištovna, fond živnostenských pokračovacích škol, zemědělský (kam plynuly pokuty „zvěropolicejni“), fond pro péči o válečné poškozence, fond pro opatření pomůcek hospodářských škol, penzijní učitelský (MZA Brno-SOkA Pelhřimov, OÚ Humpolec, inv. č. 805, kart. 242 - všeobecné záležitosti trestně-správní agendy, výkazy uložených pokut). 


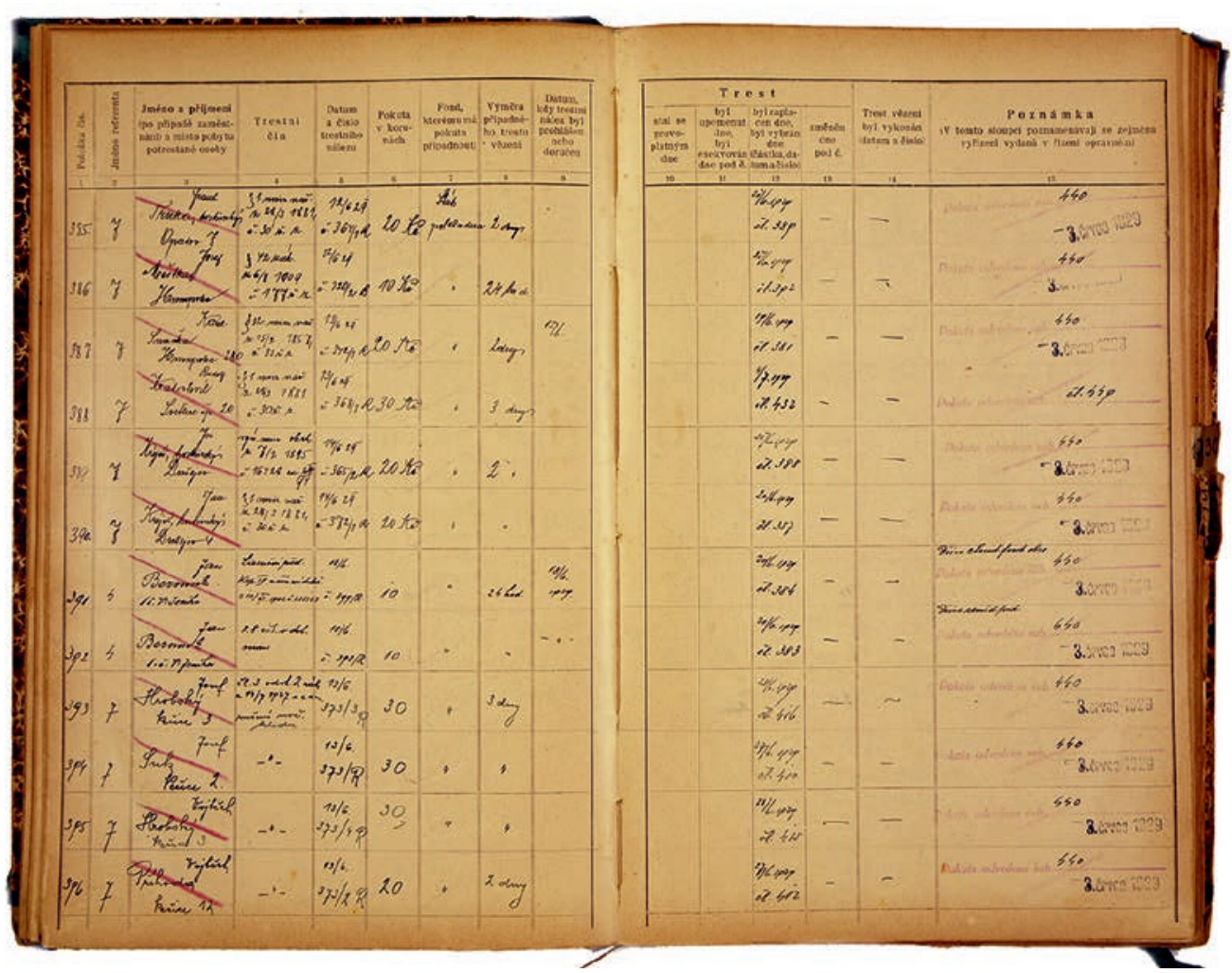

Obr. 3: Kniha uložených pokut (trestní rejstř́k) (MZA Brno-SOkA Pelhřimov, oú Humpolec, inv. č. 246, kniha č. 157- kniha evidence osob potrestaných v soudním řízení správním u okresního úřadu)

Další praktické využití knih spočívalo v každoroční (do roku 1937) potřebě pro úhrné výkazy o počtu a výši odvedených a uložených pokut. ${ }^{32}$

V průběhu 2. světové války (od roku 1942) se jednotně, chronologicky vedené knihy (knihy uložených pokut) rozštěpily a do zvláštních tř́i řad označených velkými písmeny abecedy se vyčlenily rejstř́iky evidující přestupky: A -zásobovací agendy, B - vyživovací agendy a $\mathrm{C}$ - cenové přestupky. ${ }^{33}$

V roce 1922 došlo k přesunu kompetencí lichevních soudů na okresní úřady. Ty měly zavést zvláštní záznamník (rejstřík) o správních přestupcích vládního nařízení z 3. 9. 1920 č. $516 \mathrm{Sb}$. z. lichevního zákona. Důvodem jeho vedení bylo: „aby neustalo prerušeni evidence, jež je nutnou v zájmu veřejném." Z tohoto záznamníku měly být nejpozději třetí den v každém měsíci vyhotoveny výkazy o správních přestupcích a ty postoupeny Zemské

32 MZA Brno-SOkA Pelhřimov, OÚ Kamenice nad Lipou, inv. č. 1034, kart. 511 - oběžník Zemského úřadu v Praze čj. 20/5 z r. 1935, odd. 31 z 25. dubna 1935 a 233/3 z r. 1937, odd. 31 ze 4. srpna 1937.

33 K nim blíže Šmilauerová, Eva: Správni vývoj a diplomatika písemnosti okresních národních výborů v letech 1945-1960. Sborník archivních prací 23, 1982, č. 1, s. 146-147. 
správě politické do Prahy, která je sumarizovala a výsledky předložila ministerstvu vnitra. ${ }^{34} \mathrm{~V}$ dubnu 1923 se konceptní úředník dr. Josef Drábek obrátil na zemskou správu s žádostí o zrušení výkazů a vedení záznamníku. Připomínal, že při přesunu agendy nedošlo k posílení personálu a přitom „vyhotoveni trestního nálezu nevyžádá si zdaleka tolik času, jako jeho zanášeni do „záznamu” a vedeni jeho v evidenci za přićinou předkládáni měsíčich výkazů." Z Prahy obdržel rozhodnutí, že se námitka nepřijímá, nebot není oprávněná co do podstaty, navíc z Humpolce, kde vykazovali př́ípady v řádu jednotek, tato žádost byla chápaná jako nevhodná. ${ }^{35}$ Jistě si dr. Drábek „v duchu” pomyslel své, když si v květnu roku 1927 přečetl oběžník zemské správy politické, kde se uvádělo, že „netrvá toto ministerstvo z úsporných di̛vodů na dalšim podáváni těchto periodických zpráv a upoušti od předkládáni výkazů o shora uvedených přstupcích počinajic měsicem dubnem 1927. Netřeba sem tudiž výše zminěné výkazy nadále předkládati. Ministerstvo vnitra očekává, že politické úřady I. stolice věnuji i nadále náležitou péči věcnému a urychlenému projednáni shora naznačených přestupků a také rychlému výkonu právoplatně uložených trestů."

\section{Príkazní řízení}

Specifickým typem přestupkového řízení bylo tzv. příkazní řízení (mandátní), které bylo možné v době Rakousko-Uherska a první republiky aplikovat jen u několika typů agend. Vycházelo ze skutečnosti, že úřad udělil pokutu bez dalšího úředního řízení, pouze na základě zjištěné situace. Již od 60. let 19. století bylo umožněno, aby živnostenský úřad (jímž byl okresní úřad) bez předchozího řízení vydal přímo trest, a to v podobě trestního příkazu. Podobné řízení umožňoval i $\$ 70$ zákona č. 177/1909 ř. z. o zamezení a potlačení nakažlivých zvířecích nemocí. Po roce 1918 bylo možné uplatnit podobné pokutování v případě zákona č. 122/1933 Sb. z. o změnách řádu volení v obcích, kde hrozila pokuta do výše 500 Kč, pokud se osoba nezúčastnila voleb, aniž by se omluvila. ${ }^{36}$ Se spisy uvedených přestupků se lze přirozeně setkat i v písemnostech fondů okresních úřadů.

\section{Blokové řizení}

Život člověka se v období první republiky značně „zrychloval”. Na toto zrychlení měly reagovat i správní instituce. ${ }^{37}$ Nejvýrazněji se změny promítly do agendy spjaté s automobilismem. Zatímco roku 1905 bylo v Předlitavsku registrováno 306 automobilů, roku

34 MZA Brno-SOkA Pelhřimov, OÚ Humpolec, inv. č. 805, kart. 242 - oběžník Zemské správy politické v Praze čj. 18/L 849 ai 1923, Č. z. sp. p. 110.106 z 24. března 1923.

35 Tamtéž.

36 Vetešník, Pavel: Řizeni blokové a přikazni. In: Encyklopedie českých právních dějin (XI. svazek, Řízení). Ed. Karel Schelle - Jaromír Tauchen. Plzeň - Ostrava 2018, s. 42-44.

37 Ke snahám o zrychlení a vnímání nutnosti urychlit oběh dokumentů již v době Rakousko-Uherska blíže Holub, Pavel: Hrabě Kielmansegg a jeho „účelové tisky“. Paginae historiae 26, 2019, č. 1, s. 397. 
1930 jen v Čechách bylo evidováno na 100086 aut. ${ }^{38}$ Enormní nárůst si vyžádal i změnu přístupu úřadů. Do poloviny 30. let 20. století se musel řidič při spáchání dopravního přestupku dostavit na úřad, kde následoval postup jako v případě mlynáře Kletečky či výtržníka Jakoubka. Proto byl v září roku 1926 na úřad předvolán i humpolecký továrník Richard Smrčka, aby objasnil důvod rychlé jízdy. Sám přiznal: „.. že jsem dne 12. 9. t. $r$. projižděl Pražskou ulici a jelikož toho dne v neděli o 3. hodině odpoledne byla silnice tato úplně volná (bez frekvence), jest možno, že rychlost mého motoru byla přes $20 \mathrm{~km}$. Za okolnosti těchto ovládal jsem zcela bezpečně stroj a bylo vyloučeno, že bych touto jizdou nějaké nebezpeč mohl zaviniti. Ujel jsem letošního roku přes $7000 \mathrm{~km}$ a podobný př́pad vyšetrování jsem dosud neměl." 39

$\mathrm{V}$ roce 1935 byly vydány předpisy, které do praxe zaváděly tzv. blokové řízení. V jisté míře jej můžeme označit za derivát přestupkového řízení a zjednodušenou formu příkazního řízení. ${ }^{40}$ Prvním zákonem, který umožnil aplikaci blokového řízení, byl právě zákon č. 81/1935 o jízdě motorovými vozidly. Okresní úřady musely sice nejprve vydat zmocňovací listinu pro orgány veřejné moci (např. četnictvo), aby tyto následně směly určité přestupky zmíněného zákona pokutovat a ukládat trestním příkazem na místě peněžité pokuty do maximální výše 300 Kč.

Jak se uvádělo v oběžníku, „účelem tohoto ustanoveni jest předev̌̌ím a) zjednodušeni správního trestního ř́zeni o méně závažných přestupcích, jichž skutková podstata jest nesporně zjištěna tim, že pachatel byl př́mo při činu přistižen a svoji vinu doznal a při nichž se tedy zpravidla nejevi účelným prováděti trestni řízeni v obvyklé předepsané formě; b) výchovný účinek, spojený s bezprostřednim potrestáním pachatele na mistě činu “. ${ }^{41}$

Trestní příkaz vydaný četníky byl vyhotoven ve třech průpisech, přičemž první byl určen potrestanému, druhý úřadu a třetí zůstal v pokutovém bloku. Pokud viník odmítl pokutu zaplatit, celá událost přešla do režimu běžného trestního správního řízení.

Tím, že se jednalo o zkrácené řízení, ani registratury úřadů neobsahovaly z výpovědního hlediska obsažné spisy. Pouze v knihách evidujících projednané záležitosti a pokuty je za druhé světové války uvedena souhrnně v jednom záznamu informace: „Četnická stanice XX”, a ve sloupci trestní čin „silnični pokuty” s příslušnou částkou. K výši těchto pokut vydalo roku 1937 ministerstvo vnitra informaci v oběžníku s upozorněním, že je třeba, aby „...došlá trestni oznámeni o přstupcích dopravněpolicejnich, zejména predpisů o jizdě motorovými vozidly byla co možno nejdřive projednána a aby byl vždy viniku uložen patřičný trest úměrný jeho majetkovým a výdělkovým poměrům, jenž by měl potřebný výstražný účinek. Jen tím nabudou dopravněpolicejni úřady a orgány dopravni policie náležité autority, nezbytně nutné při výkonu dopravněpolicejni služby a udržováni pořádku na silnicích...". A právě proto

38 Štemberk, Jan: Automobilista v zajetí reality. Vývoj pravidel silničního provozu v českých zemích v první polovině 20. století. Praha 2008, s. 14, 19.

39 V Humpolci jsou dochovány jako ukázky spisy projednaní pokuty za překročení rychlé jízdy automobilem, jenž řídil továrník Richard Smrčka. Výsledkem bylo odpuštění trestu (pokuty). MZA Brno-SOkA Pelhřimov, OÚ Humpolec, inv. č. 819, kart. 243.

40 Vetešník, Pavel: Řizeni blokové, s. 42.

41 MZA Brno-SOkA Pelhřimov, OÚ Humpolec, inv. č. 985, kart. 328 - oběžník ministerstva vnitra ze dne 14. ledna 1938, č. B-2242-13/1-38. 
si ministerstvo vyžádalo vypracování podrobného statistického přehledu o počtu dopravních přestupků. ${ }^{42}$

\section{Evidence soudně trestaných}

Dosud byla v tomto př́spěvku věnována pozornost trestní agendě, kdy okresní hejtmanství vykonávalo trestní správní řízení. Součástí četníkova oznámení v případu Josefa Kř́íže a Václava Jakoubka byl i výpis rozsudků odkazujících na trestnou činnost dané osoby. Tento typ agendy bychom našli vedený i v současné době (byt̃ v jiné formě). Označuje se jako Rejstř́ík trestů. V období první republiky se užívalo označení Trestní rejstř́ík. V této době byl veden v podobě knihy evidující soudní rozhodnutí trestné činnosti osob daného regionu. S titulem Trestní rejstř́k pro tuto sérii bychom se setkali u knihy z Kamenice nad Lipou. ${ }^{43}$ Pelhřimovské svazky jsou naopak označeny jako Trestní záznam. ${ }^{44} \mathrm{~V}$ př́i padě hejtmanství v Humpolci se užíval termín Rejstř́ík soudních trestů. ${ }^{45}$ Přesto se vždy jedná o týž typ písemnosti, jejímž cílem byla evidence soudních provinilců. Nadřízené instituce jej v době první republiky označovaly jako rejstř́k trestů. ${ }^{46} \mathrm{U}$ pelhřimovského úřadu jsou tyto knihy dochovány kontinuálně od roku 1868, přičemž kniha č. 96 byla vedena již od roku 1850. Obsahuje však jen jména začínající písmeny A-D. Struktura knihy je u všech fondů obdobná. Svazek je rozdělen na části, kdy každá část tvoří oddíl („reálné folium “) pro jména jednoho písmene. Pro lepší orientaci byla u starších svazků př́íjmení psána humanistickou kurzivou, zatímco ostatní text německým kurzivním písmem 19. století (kurentem). V mladším období se již užívalo obecně humanistického písma a orientaci v jednotlivých oddílech umožňoval řezaný index. Formulář knihy obsahoval: Geschäftszahl, Jahrgang / Name und Charakter des Abgeurtheilten / Zuständigkeitsort / Übertretung / Name der aburtheilenden Behörden / Urtheil / Dauer der Strafzeit / Anmerkung. Mladší knihy mají formulář uzpůsoben do podoby: Jméno a př́ijmení (Vor- und Zuname) / Stáří (Alter) / Zaměstnání (Beschäftigung) / Místo, kam př́isluší (Zustätigkeitsort) / Kdy a od kterého soudu byl odsouzen (Wann und von welchem Gerichte verurtheilt) / Přrečin neb zločin a trest (Vergehen oder Verbrechen und Strafe) / Poznamenání (Anmerkung).

Reforma ve vedení trestních lístků v roce 1923 znamenala i změny ve formuláři knihy. V této souvislosti je třeba interpretovat fakt, proč starší svazky končí roku 1922 a nové začínají rokem 1923. ${ }^{47}$ Podle oběžníku pražské zemské správy politické měly knihy obsahovat: Jméno a př́jmení, přezdívku, dobu a místo (politický okres) narození, domovskou obec (politický okres), soud, jenž rozsudek vyřkl, datum a číslo rozsudku, označení

42 Tamtéž, inv. č. 805, kart. 242 - oběžník ministerstva vnitra z 20. listopadu 1937, č. 79 219/1937-13.

43 Tamtéž, OÚ Kamenice nad Lipou, kniha č. 207.

44 Tamtéž, OÚ Pelhřimov, kniha č. 97.

45 Tamtéž, OÚ Humpolec, kniha č. 152, 153.

46 Tamtéž, OÚ Kamenice nad Lipou, inv. č. 600, kart. 161 - oběžník zemské správy politické č. 8D4595/1 ai 1923 / Č́ís. z. sp. p. 476283 z 11. prosince 1923.

47 Dobře dokumentuje Pelhřimov a Kamenice nad Lipou. 


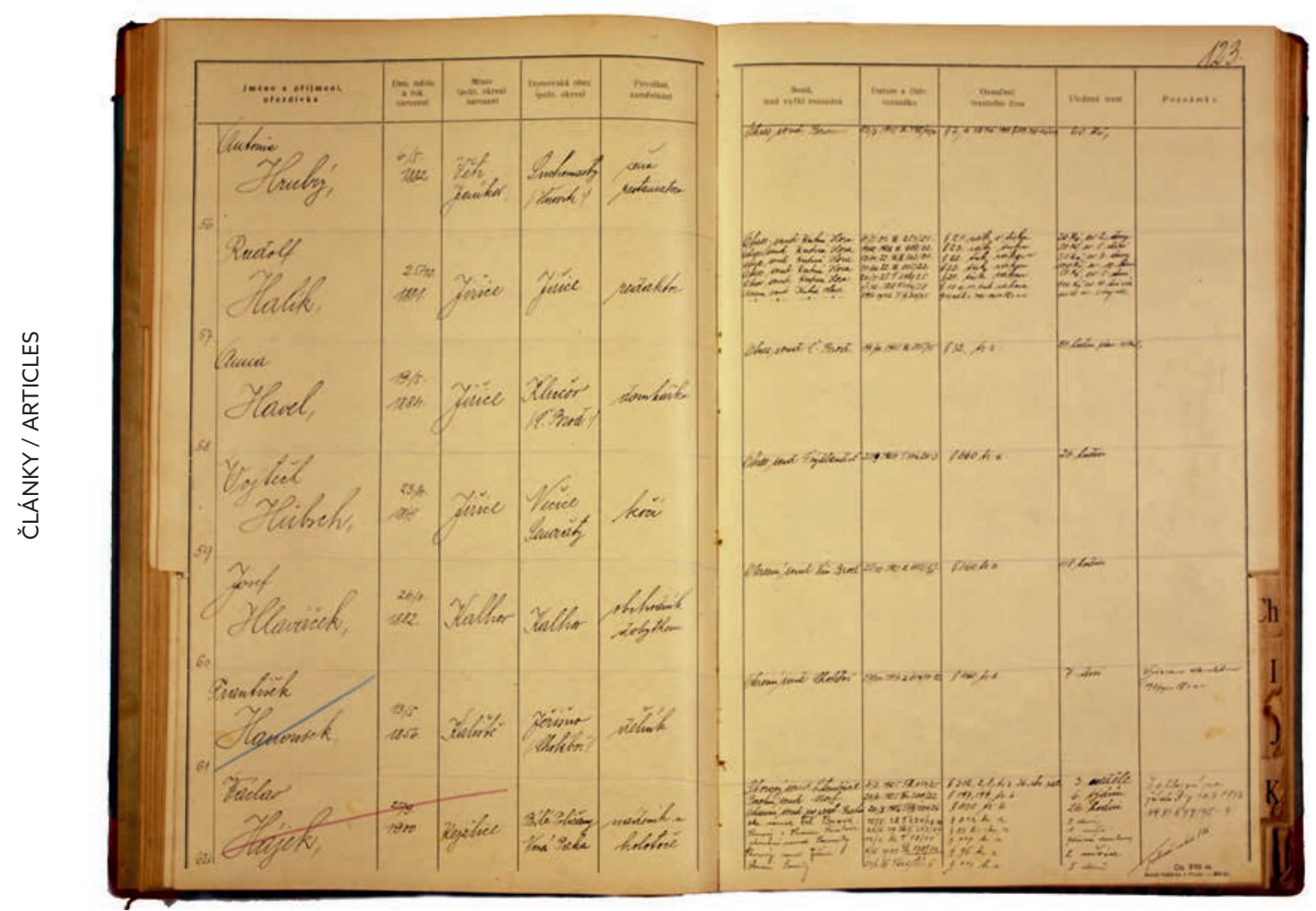

Obr. 4: Evidence soudně trestaných osob z politického okresu. Pod číslem 57 zachycen redaktor Rudolf Halík. ${ }^{48}$ (MZA Brno-SOkA Pelhřimov, OÚ Humpolec, inv. č. 241, kniha č. 152)

trestního činu a uložený trest. U dvou analyzovaných úřadů (pelhřimovský fond knihu z 20. let 20. století neobsahuje) je formulář, resp. nadepsaná rubrikace v jednotlivostech odlišná:

Humpolecká kniha obsahuje: Jméno a příjmení, přezdívka / Den, měsíc a rok narození / Místo (politický okres) narození / Domovská obec (politický okres) / Povolání, zaměstnání / Soud, jenž vyřkl rozsudek / Datum a číslo rozsudku / Označení trestného činu / Uložený trest / Poznámka. Tento formulář byl dodán Státní tiskárnou v Praze (687-24, č. $270 \mathrm{vl}$.).

Kniha vedená $\mathrm{v}$ Kamenici nad Lipou byla zřejmě vytištěna ve zdejším regionu, neobsahuje odkaz na oficiální tiskárnu. Zde je třeba hledat původ jisté nuance od uvedených položek v oběžníku: Jméno a př́ijmení / Den a rok narození / Zaměstnání / Rodiče / Místo narození / Domovská př́íslušnost / Kdy a od kterého soudu byl odsouzen / Přečin neb zločin a trest / Poznamenání / Číslo jednací.

48 Narozen 25. ř́ijna 1881 v Jiřicích u Humpolce, zemřel v Praze 27.ř́ijna 1960. Redaktor novin Havlíčkủv kraj a Venkov. K němu blíže Brzoň, Roman a kol.: Humpolec v zrcadle času III. Osobnosti. Humpolec 2012, s. 36 . 
U humpolecké knihy je uveden jako počátek vedení knihy rok 1920. Ovšem formulář odpovídá až nové formě reflektující popsané změny z roku 1922. Je tak nutné posunout dataci vzniku až za rok 1923. Analyzujeme-li zápisy humpolecké knihy důsledněji, není na první pohled zřejmé, podle jakých kritérií byly zápisy o osobách připisovány. Po zevrubném studiu se ukázalo, že zápisy (u každého písmena) byly vloženy tak, že si úředník nejprve seřadil (zřejmě) trestní listy podle místa narození a poté do knihy zapsal jednotlivá jména (proto zápisy jdou postupně od Boňkova po Želiv). Po roce 1928 byly zápisy připisovány chronologicky - zde tedy již řazení odpovídá datu rozsudku, a to až do roku 1949. ${ }^{49}$ U ostatních archivních fondů uložených v pelhřimovském archivu se podobná anomálie neobjevuje, nebot̉ odsouzení byli do knih připisováni chronologicky (byt výjimky v rozmezí několika měsíců jsou zřejmé). ${ }^{50}$

Knihy ovšem byly pouze jednou částí celé agendy. Druhou částí, která se v podstatě dodnes nedochovala, byly sbírky trestních listů (lístků). Pro muže jim byla po reformě (z roku 1923) určena žlutá barva, pro ženy červený odstín. Na jejich základě okresní úřad provedl zápis do rejstř́íku, přičemž měl povinnost doručený dokument - trestní lístek rovněž založit. Významnou změnu ve vedení knih a řazení trestních lístků, jak bylo krátce připomenuto výše, přinesl rok 1923. Dosavadní podoba vedení rejstř́ku s údaji podřazenými domovské příslušnosti byla prohlášena za nevhodnou. V návaznosti na vládní nařízení č. 198/1922 Sb. vydala zemská správa politická oběžník, na jehož základě mělo dojít od 1. ledna $1923 \mathrm{k}$ zásadní změně. ${ }^{51}$ Evidence již neměla být vedena podle domovské př́ślušnosti odsouzeného, ale podle místa narození. Toto zjištění je cenné z hlediska výpovědní hodnoty knih - trestních rejstř́íků. Úřady dostaly za úkol přepracovat své evidence a seřadit trestní listy podle místa narození. U těch osob, které se nenarodily ve správním obvodu úřadu, mělo dojít $\mathrm{k}$ jejich odeslání př́ślušnému úřadu. ${ }^{52} \mathrm{~V}$ Kamenici nad Lipou se přeřazení podařilo dokončit $\mathrm{k} 19$. květnu 1924. Ve stejném roce kutnohorská okresní správa podala návrh na úplné zrušení trestních rejstř́iků a ponechání pouhých trestních lístků. Nadřízený úřad tento návrh zamítl, nebot "pouhým zakládáním trestních listů není zaručena spolehlivá a presná evidence provinilců, nebot dotyčné trestní listy snadno mohou býti ztraceny, nesprávně zařazeny, neb při opětném použití nedopatřením i do ri̊zných spisů založeny. Jakým zpưsobem maji vésti podřizené politické úráady I. stolice tyto zuläštni záznamy bylo ponecháno volné uivaze těchto uíradũ. "Že i přesto nebylo vedení trestních rejstř́íku a řazení trestních lístků důsledně dodržováno, svědčí oběžník z roku 1936. V něm byl přímo „modelován“ celý postup od přijetí lístku až po zápis do trestního rejstř́íku. Ze zprávy humpoleckého hejtmana lze zjistit, že trestní rejstř́k i trestní listy byly v Humpolci uloženy v kanceláři „ve skř́ni a jsou vždy po ruce“. Podle hejtmanova tvrzení, byly údaje zapisovány a listy zakládány denně..$^{53}$

49 Tamtéž, OÚ Humpolec, kniha č. 152 a 153.

50 Tamtéž, OÚ Kamenice nad Lipou, kniha č. 209 a 210.

51 Tamtéž, inv. č. 600, kart. 161 - oběžník zemské správy politické č. 8D4595/1 ai 1923 / Čís. z. sp. p. 476283 z 11. prosince 1923 .

52 Tamtéž, „Jména žen vyznačená jsou na trestních listech vždy jménem dívčim v rodě mužském; jméno nabyté provdánim je vyznačeno v závorce".

53 Tamtéž, OÚ Humpolec, inv. č. 535, kart. 44 - prezidiální spisy, spis č. 528/1936. 
Trestní rejstříky vedly rovněž i obecní úřady, a to na základě sdělení zasílaných okresním úřadem. Tyto rejstř́íky měly starostům sloužit za podklad pro vydávané zprávy o zachovalosti. Jak ovšem zjistil po nástupu do humpoleckého úřadu Vojtěch Vaniš, v některých obcích byla situace natolik tristní, že nedisponovali ani knihou, natož aby do ní zapisovali údaje. ${ }^{54}$

\section{Závěr}

Agenda trestního správního řízení představuje bohatý zdroj informací o životě obyvatelstva daného regionu. Přestože mnohé normy byly vydány již v padesátých letech 19 . století, byly platné i v období první republiky. Základními právními předpisy, které toto řízení u politických úřadů upravovaly, byly: nařízení č. 96/1854 ř. z., č. 61/1855 ř. z., č. $34 / 1858$ ř. z. a 129/1858 ř. z.

Proměna společnosti a zrychlení tempa života si vynutilo i zrychlení trestního řízení. Roku 1936 bylo do praxe zavedeno tzv. blokové trestní řízení vládním nařízením č. 51/1936 Sb. z., na jehož základě mohly i okresní úřady k výkonu trestního řízení zmocnit např. četnictvo. Analýza písemností někdejšího Okresního úřadu Humpolec ukázala různé typy písemností, které byly pro tuto agendu typické. Přitom nejčetněji užitým označením pro písemnost je „trestní rejstř́ík“, byẻ jeho význam nebyl vždy zcela jednoznačný. $\mathrm{V}$ pramenech se lze s tímto termínem setkat pro písemnosti evidující projednávané trestně-správní řízení u okresního úřadu. Stejně tak se za trestní rejstř́ík označovala kniha evidující odsouzené osoby. Ve skupině spisového materiálu byl trestním rejstř́íkem chápán formuláŕ pro záznam o celém trestním řízení.

Aby bylo zabráněno terminologickým nejasnostem, bylo by vhodné zavést nové označení pro jednotlivé typy písemností. Již ve své době byly knihy evidující projednávané trestní řízení označeny jako Knihy pokut, zatímco evidence soudně trestaných byla chápána jako evidence odsouzených osob. U posledně zmíněné série by se autor ovšem přikláněl k ponechání označení Trestní rejstřík.

54 Tamtéž, inv. č. 805, kart. 242 - všeobecné záležitosti trestně správní agendy, koncept pro úřední list z 6. dubna 1911. 


\section{Criminal Records from the Political Office of the first Instance of State Administration at the Beginning of the 20th Century, as Exemplified by Documents from Humpolec}

The administration of criminal proceedings is a rich source of information on the life of the population of any given region. Although many regulations were issued as early as the $1850 \mathrm{~s}$, they continued to be valid during the First Czechoslovak Republic.

Changes in society and the increasing pace of life also forced an acceleration in criminal proceedings. In 1936, so-called block criminal proceedings were introduced by the government regulation No. 51/1936 Coll. ${ }^{55}$, which also gave district authorities the power to authorize the gendarmerie, for example, to conduct criminal proceedings. During the Second World War, the form of accounting for criminal activity connected primarily with the economy forced new regulations. More detailed specifications were later laid down by individual laws that pertained to particular fields of human activity, for example, the trade licensing code.

An examination of documents of the former District Office of Humpolec revealed various types of documents that were typical for this kind of administrative work. Although the most frequently used term is criminal register, the meaning of it was not always clear. In some sources, this term refers to a document registering criminal administrative proceedings at the district office. Similarly, the book for registering persons convicted of offences was also known as a criminal register. In the group of file material, criminal register designated a form for recording the entire criminal proceedings.

55 The government regulation concerning the organization of police administration and services and other measures in the area of internal administration. 
